ред. д.е.н. О. П. Крайник. - Львів: ЛРІДУ НАДУ, 2011. - 288 с.

5. Карташов Є. Г. Державне управління стійкістю регіональних еколого-економічних систем: теорія, методологія, практика : монографія / Є. Г. Карташов. - К. : ТОВ «ДКС Центр», 2015. $-378 \mathrm{c}$.

6. Тур О. М. Формування екологоекономічного механізму стратегії екологоорієнтованого розвитку національної економіки / О. М. Тур // Механізм регулювання економіки. - 2011. - № 4. - C. 39-43.

7. Малыш Н.А. Механизм реализации геоэкономической стратегии экологической политики / Н.А. Малыш // Проблемы управления. - 2010. - № 4 (37). - С. $96-99$.

8. Мельник Л. Г. Екологічна економіка: підручник / Л. Г. Мельник. - 2ге вид., випр. і доп. - Суми: ВТД «Університетська книга», 2003. - 348 с.

9. Hoepner, A. G. F., B. Kant, B. Scholtens, and P.-S. Yu (2013) Is the journal Ecological Economics really in itself a poor and misleading guide to what ecological economics is about? A reply to "Influencing the perception of what and who is important in ecological economics" Ecological Economics 89, 174-176.

УДК 658:620.9:330.341.1(477)

\title{
ОСОБЛИВОСТІ ФОРМУВАННЯ НАЦОНАЛЬНОГО Й РЕГІОНАЛЬНОГО РИНКУ ЕЛЕКТРОЗАПРАВНИХ СТАНЦІЙ
}

\author{
Полякова О.М., к.е.н., доцент, \\ Островерх Г.С., аспірант, \\ Колесніков М.О., магістр (УкрДУЗТ)
}

У статті розглянуті нові погляди щзодо проблеми розвитку сфери електрозаправних станщій в Україні. Проаналізовано існуючий ринок електрозаправок, виявлено особливості формування ринку електрозаправних станцій в Украӥні та визначено перспективи його розвитку. Розглянуто бізнесс-модель реалізачії $i$ поліпшення кількості продажів електрозаправок для електромобілів.

Ключові слова: електромобіль, електроавтозаправна станція, енергосистема, бізнес-модель, інновації, розвиток, енергетика.

\section{ОСОБЕННОСТИ ФОРМИРОВАНИЯ НАЦИОНАЛЬНОГО И РЕГИОНАЛЬНОГО РЫНКА ЭЛЕКТРОЗАПРАВОЧНЫХ СТАНЦИЙ}

\author{
Полякова Е.Н., к.э.н., доцент, \\ Островерх Е., аспирант,
} Колесников М.А., магистр (УкрГУЖТ)

В статье рассмотрень новые взгляды на проблемы развития сферы электрозаправочных станщий в Украине. Проанализирован существующий рынок электрозаправок, выявлены особенности формирования рынка электрозаправочных

(C) Полякова O.M., Островерх Г.С., Вісник економіки транспорту і промисловості № 64, 2018 Колесніков М.О. 
станщий в Украине и определены перспективы его развития. Рассмотрена бизнессмодель реализачии и улучшения количества продаж электрозаправок для электромобилей.

Ключевые слова: электромобиль, електроавтозаправна станция, энергосистема, бизнес-модель, инновации, развитие, энергетика.

\title{
FEATURES OF THE FORMATION OF THE NATIONAL AND REGIONAL MARKET OF ELECTRIC FILLING STATIONS
}

\author{
Polyakova O. Candidate of Economic Sciences, Associate Professor, \\ Ostroverkh H., post-graduate student, \\ Kolesnikov M., master's degree (USURT)
}

The article considers new views on the problems of development of the sphere of electric filling stations in Ukraine. The existing market of electric stations was analyzed, features of the formation of the market of electric stations in Ukraine were identified, and prospects for its development were determined. In Ukraine, the electric car market is developing rapidly, which requires the rapid development of the infrastructure of charging stations. Market relations in the field of electric power are formed under the influence of internal and external factors, including the dependence of the industry on the state and dynamics of the development of world and national fuel markets; the specifics of the formation of demand, supply and prices for electricity; imperfection of the financial and credit system of the country.

Ensuring the effective functioning of the market of electric filling stations requires the creation of a competitive environment, balancing the various economic interests of market participants, the formation of market infrastructure, and the conditions for the introduction of various forms of regional cooperation.

The article proves the need to expand the network of charging stations based on the development of a business model for financing the development of infrastructure for charging electric vehicles. The proposed project provides, in addition to the definition of groups of electricity consumers, the study of functions of needs, as well as technologies to meet them.

Keywords: electric car, electric station, power system, business model, innovation, development, energy.

Постановка проблеми та ї̈ зв'язки з науковими чи практичними завданнями. Прагнення України подолати економічне відставання із подальшою інтеграцією у світове співтовариство зумовлює необхідність формування інноваційної моделі розвитку, становлення якої $\epsilon$ можливим за умови структурних перетворень економіки країни та іiі регіонів, новаційних зрушень у виробничій та соціальній сферах, реформування електроенергетичної галузі.

Одним із актуальних напрямів інноваційної діяльності енергетичних компаній $\epsilon \quad$ впровадження електроавтозаправних станцій, які набувають популярності через їх екологічність та економічність. Ринок електрозаправних станцій, як ринок одного виду товару i ряду супутніх послуг, спрямованих на забезпечення процесу купівлі-продажу електричної енергії для автомобілів, може здійснити істотний вплив на економіку України та стимулювати іiі розвиток.

На сьогоднішній день електротранспорт стрімко розвивається у всьому світі. Новий напрям отримав великий стрибок завдяки науковим відкриттям i необхідність переходу на 
відновлювані джерела енергії. За прогнозами світових експертів, до 2020 року частка електромобілів досягне 5-10\% від загального числа автомобілів в світі, на сьогоднішній день вона складає менше $0,02 \%$ [10]. За даними Bloomberg New Energy Finance, до 2040 року електрокари складатимуть не менш 54\% 54\% від числа всіх автомобілів, які будуть продаватися в світі [1].

В Україні ринок елктромобілів інтенсивно розвивається, щорічний приріст становить понад $150 \%$; за прогнозами фахівців в 2018 році кількість електромобілей мала збільшитися з 4000 до 8000 електромобілів, але всього лише за три місяці поточного року вона зросла до 8500 шт. [2]. В перспективі до 2028 року стратегією розвитку ринку електрокарів планується довести частку екологічного транспорту на автомобільному ринку України до 20-25\%.

Зрозуміло, що це вимагає стрімкого розвитку інфраструктури зарядних станцій. На жаль, поки що в питаннях обслуговування електромобілей та їх зарядки в Україні є певні прогалини. Для забезпечення розвитку ринку електромобілей по всій країні держава i місцеві органи самоврядування повинні створити комфортні умови та відповідну інфраструктуру для зарядки електромобілів як в містах, так і на трасах. 3 огляду на це розробка теоретичних аспектів та прикладних рекомендацій щодо формування та забезпечення розвитку ринку електрозаправних станцій в Україні $\epsilon$ актуальним завданням та потребує дослідження і наукової оцінки.

Аналіз досліджень $і$ публікацій. Рішенням проблеми, пов'язаної 3 інфраструктурою зарядних станцій займаються вчені всього світу.

Напрями вирішення проблем функціонування та формування національного та регіонального ринку електроенергії досліджували в своїх працях С. П. Сонько [3], Я. І. Олійник [4], О. С. Дупак [5], С. Кулицький [6] та інші.
Особливості державного регулювання електроенергетики України досліджено у працях О.В.Долгальової [7 ], Франчука I. А. [8 ], О.М.Губрієнко [9]. Питанням формування мережі електрозаправних станцій присвячені роботи О.Ю. Хрипунової та А.І. Копніної [10].

Огляд наукових джерел свідчить про посилення уваги дослідників щодо формування ринкових відносин в сфері виробництва та споживання електроенергії, особливостей та специфіки формування національного й регіонального (роздрібного) ринку електроенергії, обгрунтування напрямів розвитку ринку електроенергії, принципів його функціонування, а також шляхів удосконалення системи відносин між основними суб' єктами цього ринку.

Разом 3 тим, незважаючи на підвищений інтерес з боку науковців до питань розвитку ринку електроенергії та формування на ньому ринкового середовища, наразі існує потреба в подальшому висвітленні теоретичних i методичних засад формування й функціонування ринку електроенергії 3 метою забезпечення подальшого його стабільного розвитку.

Mema cmammi. Метою публікації $\epsilon$ виявлення особливостей формування ринку електрозаправних станцій в Україні та визначення перспектив його розвитку.

Викладення основного матеріалу. Ринкові відносини в галузі електроенергетики формуються під впливом дії зовнішніх та внутрішніх факторів [11, с. 133].

Перша група факторів пов'язана зі зміною зовнішніх відносин в галузі.

Найважливішими 3 них є:

- наявність тісного господарського контакту між галуззю як постачальником електроенергії з усіма підприємствами, що вступили на шлях ринкових відносин;

- залежність галузі як споживача від стану та динаміки розвитку світових та національних ринків палива, сировини, матеріалів, обладнання; 
- специфіка формування попиту, пропозиції та ціни на електроенергію як товар в умовах поширення ринкових відносин в економічній системі країни;

- необхідність формування адекватного світовим вимогам механізму забезпечення ринкових реформ в галузі;

- відповідність

параметрів розвитку

сучасних

електрозаправних станцій стратегічним завданням реформування національної економіки та її регіональних складових, що мають базуватися на ринкових відносинах;

- недосконалість фінансово-

кредитної системи країни, що вимагає розроблення нової схеми відносин суб'єктів національного ринку електроенергії, а також необхідність формування більш досконалої політики ціноутворення на електроенергію як товар та механізму формування тарифів.

Друга група факторів пов'язана із необхідністю здійснення ринкових реформ стосовно розвитку ринку електрозаправних станцій 3 метою підвищення попиту на електроавтомобілі.

Існують також й інші специфічні фактори, що ускладнюють процеси ринкових перетворень

електроенергетиці:

- по-перше, виробництво й споживання електроенергії поєднані в часі, відповідно таку продукцію не можна виробити й закупити наперед, наприклад, в очікуванні покращення кон'юнктури ринку, збільшення цін на енергію чи перебоїв в електропостачанні для заправок. Тому на ринку електрозаправних станцій велика увага повинна приділятися питанням прогнозування попиту не тільки за величиною, але й за часом, оскільки завищення попиту призведе до заморожування великих інвестицій, а його заниження може бути пов'язане зі значними збитками для енергопостачальних компаній через зниження надійності електропостачання; - по-друге, електрозаправних станцій ринки можуть формуватися i діяти лише за умови нерозривності передачі, розподілу й використання електроенергії. Отже, об'єктивною необхідністю виступає формування об'єднаної мережі електрозаправних станцій, досконалої системи технічного супроводу розвитку галузі та ринкових відносин (комерційних). Це вимагає дотримання певних правил, які зобов'язують будьякого власника електромереж забезпечити рівноправне обслуговування будь-яких господарюючих суб'єктів і тим самим забезпечувати сприятливість конкурентного ринкового середовища [12]; - по-трете, основними параметрами дослідження ринку електрозаправних станцій як товару, поряд iз фізичним обсягом електроенергії $\epsilon$ потужність, час, режим споживання, якість (відповідність певним стандартам). Отже, за умов формування збалансованого ринку електрозаправних станцій (збалансування попиту i пропозиції) конкуренція між виробниками i постачальниками енергії може відбуватися лише за рахунок цінових факторів, пропозиції іï за нижчими цінами. Відмітимо, що теоретично збалансований ринок являє собою такий ринок товарів, на якому пропозиція відповідає попитові за кількістю, асортиментом і якістю.

$$
\text { Варто зазначити, що }
$$

електротранспорт і інфраструктура електрозаправок входять в технологію Smart City, яка $\epsilon$ частиною глобальної Vehicle-to-grid (V2G) - концепції двостороннього використання електромобілів і гібридів, що передбачає підключення машин в загальну енергомережу для підзарядки автомобілей і віддача зайвої електроенергії назад. У власників автомобілів 3 технологією V2G буде можливість продавати електроенергію енергетикам в години, коли машина не використовується, i заряджати автомобіль в години, коли електроенергія дешевша; в багатьох країнах ціна електроенергії залежить від часу доби. 
Також буде можливість підключати автомобілі з цією технологією до власних будинків і використовувати їх в якості безперебійного живлення для будинків або офісів. V2G-технологія зараз широко розвивається урядом США і компанією Google.

Всі розвинені країни намагаються підтримувати перехід на електромобілі. Так, в Японії і США проводиться федеральне субсидування покупців таких машин, крім того, електрокари - велика стаття в закупівлях для держпотреб в Європі і США. Крім цього, в більшості країн популярність електромобілів підвищується за рахунок скасування плати за парковку для екологічних машин, зниження або повного обнулення транспортного податку, звільнення від разових податкових зборів при покупці авто. Зарядна інфраструктура в європейських країнах вже кілька років не $\epsilon$ якоюсь проблемою. Наряду з невеликими приватними компаніями, найбільші гравці ринку розгорнули програми по відкриттю сотень точок доступу до електроживлення.

На цьому тлі український ринок фактично не має державної підтримки i сильно відстає: поки автопарк електромобілів в Україні становить трохи більше 1000 одиниць. Однак перспектива очевидна: навіть залишаючи за межами екологічні питання, в нинішній економічній ситуації в Україні пересуватися на електромашинах виявиться дешевше, ніж використовувати бензинові автомобілі.

Підготовку до забезпечення розвитку цього напряму необхідно починати з процесу змін і переходу на альтернативні засоби пересування електромобілі. Також необхідно змінювати законодавство і закладати в інфраструктурні проекти ті норми, які прискорять впровадження інновацій в повсякденне життя. Існуючі темпи росту кількості електромобілів в Україні та скасування податків на їх імпорт стимулюватимуть український бізнес до інвестицій в інфраструктурні проекти. Державним органам влади варто, перш за все, надати можливість цьому ринку «народитися». Але поки що доводиться констатувати, що ніякої серйозної законотворчої роботи в цьому напрямку в Україні не ведеться.

За різними даними в Україні нараховується близько 600-800 зарядних станцій. Більшість 3 них $(95 \%) \quad \epsilon$ повільними. Зарядка найбільш розповсюдженої в Україні моделі електромобіля Nissan Leaf на них може займати від 2 до 5 годин. Це, безумовно, стримує розвиток електротранспорту в Україні. Потужний поштовх він отримає 3 появою високоякісних зарядних станцій потужність в 50 кВтүгод і більше. На них зарядка буде тривати від 15 хв (для Nissan Leaf) до 1 години (для Tesla).

В той же час повільні зарядні станції $\epsilon$ оптимальним рішенням для нічних паркінгів в житлових масивах. Тут повинен бути налагоджений конструктивний діалог між власниками паркінгів (де зарядна станція може бути встановлена), мережевими компаніями (до мереж яких зарядна станція може бути підключена) i зацікавленими власниками електромобілів. Це нелегкий процес, тому що може бути велике різноманіття рішень в залежності від того, кому належить паркінг, чи є вільна потужність, скільки буде коштувати прокладка кабелів тощо.

В таблицях 1-2 представлений аналіз існуючого ринку електрозаправок в Україні на прикладі найбільшого забудовника цієї ніші (кількість заправок АвтоЕнтерпрайз - це $85 \%$ від загальної кількості зарядних станцій в Україні). 


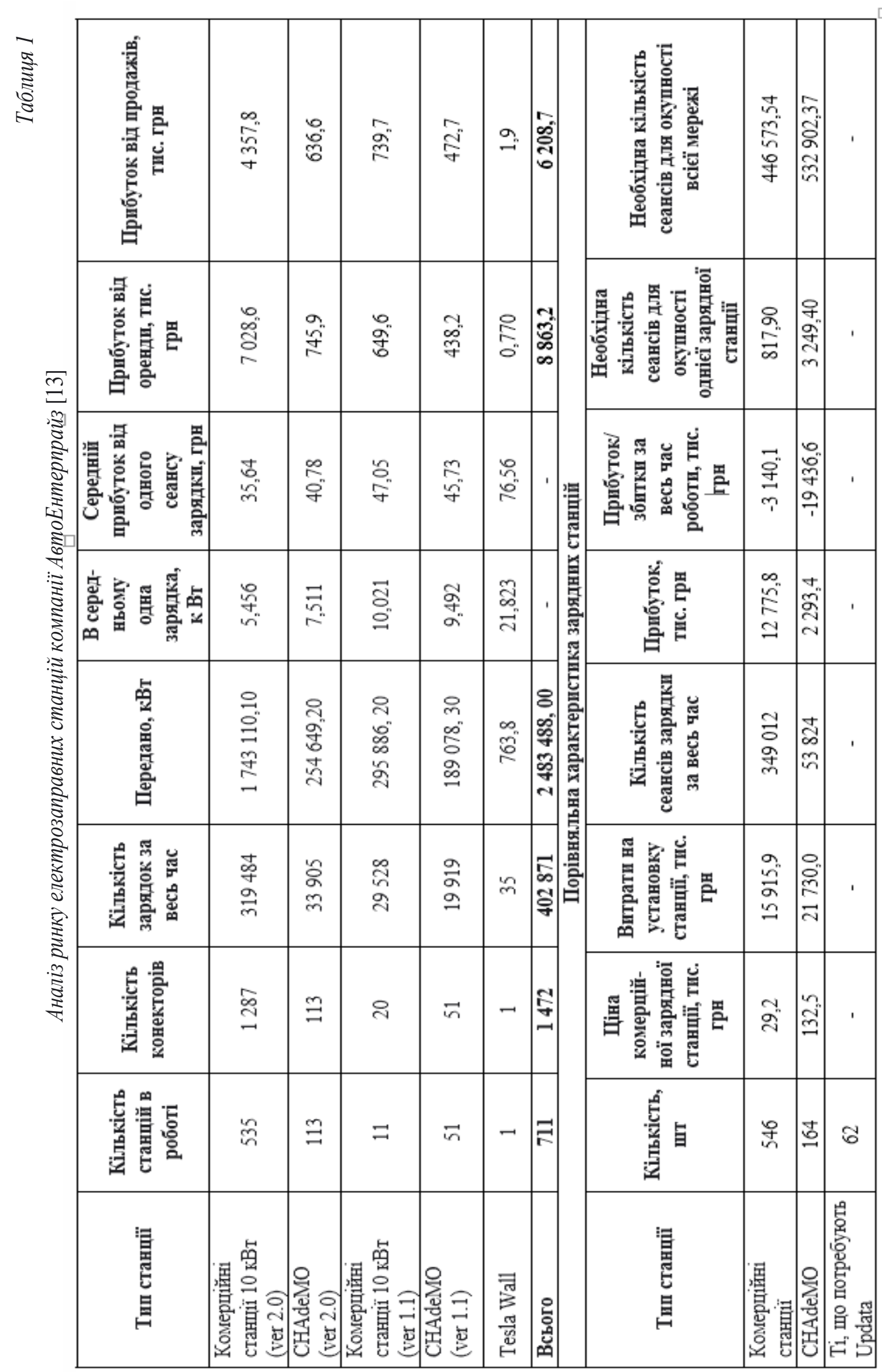

Вісник економіки транспорту і промисловості № 64, 2018 
Таблиия 2

Аналіз ринку електрозаправних станцій компанії АвтоЕнтерпрайз [13]

\begin{tabular}{|c|c|c|c|c|c|c|}
\hline $\begin{array}{c}\text { Інтервал } \\
\text { часу }\end{array}$ & $\begin{array}{c}\text { Кількість } \\
\text { машин, } \\
\text { одночасно } \\
\text { заряжающихся } \\
\text { на всіх } \\
\text { станціях, шт. } \\
\end{array}$ & $\begin{array}{c}\text { Прибуток } \\
\text { на годину } \\
\text { при } \\
\text { оренді } \\
\text { 22,00 грн }\end{array}$ & $\begin{array}{c}\text { Прибуток } \\
\text { від } \\
\text { оренди в } \\
\text { день за } 12 \\
\text { годин, грн }\end{array}$ & $\begin{array}{c}\text { Прибуток } \\
\text { від } \\
\text { оренди в } \\
\text { рік, грн }\end{array}$ & $\begin{array}{c}\text { Окупність } \\
\text { комерційних } \\
\text { зарядних } \\
\text { станцій, днів }\end{array}$ & $\begin{array}{c}\text { Окупність } \\
\text { комерційних } \\
\text { зарядних } \\
\text { станцій, міс. }\end{array}$ \\
\hline 9:00 & 90 & 1980,00 & \multirow{13}{*}{30238} & \multirow{13}{*}{11036926} & \multirow{13}{*}{526} & \multirow{13}{*}{19} \\
\hline $10: 00$ & 106 & 2332,00 & & & & \\
\hline $11: 00$ & 110 & 2420,00 & & & & \\
\hline $12: 00$ & 105 & 2310,00 & & & & \\
\hline $13: 00$ & 120 & 2640,00 & & & & \\
\hline $14: 00$ & 136 & 2992,00 & & & & \\
\hline $15: 00$ & 117 & 2574,00 & & & & \\
\hline $16: 00$ & 132 & 2904,00 & & & & \\
\hline $17: 00$ & 149 & 3278,00 & & & & \\
\hline $18: 00$ & 123 & 2706,00 & & & & \\
\hline $19: 00$ & 98 & 2156,00 & & & & \\
\hline $20: 00$ & 103 & 2266,00 & & & & \\
\hline $21: 00$ & 100 & 2200,00 & & & & \\
\hline Середнє & 115 & - & - & - & - & - \\
\hline $\begin{array}{c}\text { Мінімальні } \\
\text { показники }\end{array}$ & 80 & 1760 & 21120 & 7708800 & 754 & 27 \\
\hline
\end{tabular}

Виходячи 3 наведених даних (таблиці 1-2), можна стверджувати, що комерційні повільні станції мають невисоку вартість і починають приносити прибутки при нормальній завантаженості вже після 19 місяців роботи, при низькій завантаженості - після 27 місяці роботи.

Розширення мережі зарядних станцій, на наш погляд, можливо забезпечити на основі розробки бізнесмоделі фінансування розбудови інфраструктури для зарядки електромобілів «Invest to green technology».

Умови інвестиції:

- приймаються суми кратні 3000 \$ під 33,84\% річних;

- прийняті вклади повертаються після закінчення терміну договору або дострокового його розірвання 3 боку інвестора;

- виплати відсотків за користуванням грошима інвестора проводиться щомісяця, та здійснюється датою підписання договору;

- при підписанні договору інвестору передається в заставу вже встановлені і працюючі громадські зарядні станції власного виробництва;

- інвестору надається доступ до зарядки свого електромобіля в мережі АвтоЕнтерпрайз за собівартістю без плати за простій (плата, стягується за блокування місця для інших автомобілів після завершення зарядки);

- договір підписується на 1 рік 3 автоматичною пролонгацією;

- розірвання договору 3 боку інвестора здійснюється в будь-який час 
згідно письмового повідомлення за 2 місяці до дати розірвання.
Суми вкладів та сплат приведені в таблиці 3.

Суми вкладів та сплат [авторська розробка]

\begin{tabular}{|c|c|c|}
\hline $\begin{array}{c}\text { Кількість } \\
\text { інвестиційних пакетів }\end{array}$ & $\begin{array}{c}\text { Відсоткова ставка на } \\
\text { місяць / на рік }\end{array}$ & Виплати на місяць / на рік \\
\hline 1 & $2,82 \% / 33,84 \%$ & $84,6 \$ / 1015,2 \$$ \\
\hline 2 & $2,82 \% / 33,84 \%$ & $169,2 \$ / 2030,4 \$$ \\
\hline 3 & $2,82 \% / 33,84 \%$ & $253,8 \$ / 3045,6 \$$ \\
\hline 4 & $2,82 \% / 33,84 \%$ & $338,4 \$ / 4060,8 \$$ \\
\hline
\end{tabular}

За даним проектом «Invest to green technology» - ми отримуємо інвестиції, що дозволять стрімко збільшувати кількість електрозаправних станцій по Україні та 3 кожним новим вкладником збільшується здатність виплати відсотків вкладів інвесторам і окупність мережі зарядних станцій. Запропонований проект передбачає, крім визначення груп споживачів електроенергії для автомобілів як товару, вивчення функцій потреб (які саме потреби задовольняються, зміни потреб тощо), а також технологій задоволення цих потреб (адресність, послуг, їх індивідуалізація, достатність тощо).

Висновки. Проведений аналіз стану і тенденцій розвитку електротранспорту в світі і в Україні показав, що в найближчі роки їх кількість істотно зросте, що, в свою чергу, потребує нарощування зарядної інфраструктури, практично не розвинутої на сьогоднішній день.

Забезпечення ефективного функціонування ринку електрозаправних станцій вимагає створення конкурентного середовища, збалансування різноманітних економічних інтересів учасників ринкових відносин у його межах, формування ринкової інфраструктури, а також умов для запровадження різних форм регіонального співробітництва.

Головним завданням подальшого розвитку ринку електрозаправних станцій (як національного, так і регіонального) $\epsilon$ досягнення оптимальних пропорцій між дією ринкових механізмів і механізмів державного регулювання. Це вимагає грунтовного дослідження основних етапів становлення ринкових механізмів розвитку галузі. Таким чином, розвиток в Україні ринкових відносин у сфері електрозаправних станцій вимагає дослідження формування регіональних (роздрібних) ринків електроенергії та визначення шляхів поєднання ринкових механізмів та механізмів державного регулювання 3 метою забезпечення їх розвитку.

\section{СПИСОК ВИКОРИСТАНИХ ДЖЕРЕЛ}

\begin{tabular}{lcr}
1 & Украина & \multicolumn{2}{c}{ стремительно } \\
наращивает & инфраструктуру для \\
электромобилей & [Електронний & ресурс].- \\
Режим & доступу
\end{tabular}

https://www.segodnya.ua/economics/avto/u kraina-stremitelno-narashchivaet infrastrukturu-dlya-elektromobiley1070005.html

2 В Украине хотят довести долю электромобилей до 20-25\% к 2028 году [Електронний ресурс].- Режим доступу : http://www.autoconsulting.com.ua/article.p $\mathrm{hp}$ ?sid=41029

3. Сонько С. П. Ринок i регіоналістика [Текст]: Навч.посібник / C. П. Сонько, В. В. Кулішов, В. І. Мустафін. - К. : Ельга, Ніка-Центр, 2002. — 287 с.

4 Олійник Я. І. Розробка державної програми розвитку електроенергетики Західного регіону України [Текст] / Я. I. Олійник // Вісник Хмельницького 
національного університету. - 2010. Т. 3, № 2. - С. $169-172$.

5 Дупак О. С. Інформаційноаналітичне дослідження стану паливноенергетичного комплексу України [Текст] / O. С. Дупак // Електроінформ: Енергетика. Електротехніка. Електроніка. - 2006. - № 1. - С. $7-10$.

6 Кулицький С. Економічна ситуація в електроенергетиці України: стан і перспективи [Текст] / С. Кулицький // України: події, факти коментарії. 2008. - № 22. - С. $16-33$.

7 Долгальова О. В. Державне регулювання електроенергетичної галузі України [Текст] / О.В. Долгальова // Науково-виробничий журнал Держава та регіон: Серія: Державне управління. 2009. — № 3. - С. $33-37$.

8 Франчук I. А. Державна політика розвитку енергетики в Україні: стан, тенденції, перспективи [Текст]: [монографія] / I. А. Франчук. - Донецьк: ТОВ «Юго-Восток, Лтд», 2008. - 356 с.

9 Губрієнко О. Теоретикоправовий аналіз деяких функцій державного управління в галузі енергетики в Україні / О. Губрієнко // Підприємництво, господарство і право.2004.- № 5.- С.113-116.

10 Хрипунова О.Ю., Копнина А.И. Анализ перспектив строительства электроавтозаправочных станций в республике башкортостан // Вестник УГНТУ. Наука, образование, экономика. Серия: Экономика, - 2017. - №2 (20). - С. 114-120

11 Волкова И. О. Проблемы формирования оптового рынка электроэнергии и мощности [Текст] / И. О. Волкова, В. Р. Окороков, Ю. А. Соколов. - К. : Об-во «Знание» Украины, 1998. - 20 с. 10.Косар Н. С. Адаптація енергопостачальних компаній до ринкових умов функціонування на засадах маркетингу [Текст]: дис... кандидата екон. наук: 08.06.02 / Косар Наталія Степанівна. - Л., 1999. - 278 с.

12 Kocap H. С. Адаптація енергопостачальних компаній до ринкових умов функціонування на засадах маркетингу [Текст]: дис... кандидата екон. наук: 08.06.02 / Косар Наталія Степанівна. - Л., 1999. — 278 с.

13 Офіційний сайт AutoEnterprise [Електронний ресурс]. - Режим доступу: https://www.autoenterprise.com.ua

14 Дикань В. Л. Стратегічне управління конкурентоспроможністю як чинник інноваційного розвитку підприємства //Маркетинг: теорія i практика. Зб. наук. праць Східноукраїнського національного університету імені Володимира Даля. Вип. - 2010. - T. 16. - C. 55-58.

\title{
УДК 339.944:004
}

\section{СУЧАСНІ ТЕНДЕНЦІЇ РОЗВИТКУ ІТ-ІНДУСТРІЇ В УКРАЇНI I CВITI}

\author{
Полякова О.М., к.е.н., доцент, \\ Ромащенко О.В., махістр (УкрДУЗТ)
}

В статті розглянуто сучасний стан вітчизняної галузі інформаџійних технологій. Досліджено тендениії, які спостерігаються на ринку IT впродовж останніх

(C) Полякова O.M., Ромащенко О.В.
Вісник економіки транспорту і промисловості № 64, 2018 